\title{
Pengaruh Efektivitas Penggunaan Dana BPUM, Penggunaan Software Akuntansi, dan Human Capital Terhadap Kinerja Usaha Mikro (Studi Pada Usaha Mikro Penerima Dana BPUM di Kecamatan Buleleng)
}

\author{
Komang Tri Widya Malini ${ }^{1 *}$, Nyoman Trisna Herawati ${ }^{2}$ \\ ${ }^{123}$ Program Studi S1 Akuntansi, Universitas Pendidikan Ganesha,Singaraja, Indonesia \\ *trywidyamalini@gmail.com ${ }^{1 *}$
}

\section{Abstrak}

Penelitian ini bertujuan untuk memperoleh bukti empiris pengaruh efektifitas penggunaan dana BPUM, penggunaan software akuntansi, dan human capital terhadap kinerja usaha mikro. Penelitian ini merupakan penelitian kuantitatif kausalitas dengan menggunakan data primer yang diperoleh dari kuisioner dan diukur dengan menggunakan skala likert. Populasi penelitian ini adalah usaha mikro yang menerima BPUM, yang terdata di Bank BRI Kanca Singaraja berjumlah 6970 usaha mikro. Teknik pemilihan sampel menggunakan purposive sampling dan diperoleh jumlah sampel sebanyak 100 usaha mikro. Teknik analisis data yang digunakan adalah analisis regresi linier berganda dengan menggunakan SPSS 16.0 for Windows. Hasil penelitian ini menunjukan bahwa secara parsial efektivitas penggunaan dana BPUM, penggunaan software akuntansi, dan human capital berpengaruh positif dan signifikan terhadap kinerja usaha mikro.

Kata Kunci: Kinerja Usaha Mikro, Efektivitas Penggunaan Dana BPUM, Penggunaan Software Akuntansi, dan Human Capital

\section{Abstract}

This research aimed at gaining empirical evidences on the effect of the effectiveness in using BPUM funds, use of accounting software, and human capital on micro business performance. This research was a causality quantitative research with the primary data collected from questionnaires and measured with likert scale. The population of this research were micro businesses that receive BPUM, which are recorded at Bank BRI Kanca Singaraja as many as 6970 micro businesses. The sampling technique used purposive sampling and obtained the number of samples as many as 100 micro enterprises. The technique of analysing data applied was multiple linear regression analysis using SPSS 16.0 for Windows. The results of this research indicate that partially the effectiveness in using BPUM funds, use of accounting software, and human capital had a positive and significant effect on the micro business performance.

Keywords: Micro Business Performance, Effectiveness In Using BPUM Funds, Use Of Accounting Software, and Human Capital

\section{Pendahuluan}

Saat ini Indonesia sedang gencar gencarnya menghadapi masalah pandemi COVID 19. Pandemi COVID 19 yang terjadi saat ini memberikan dampak di segala aspek kehidupan, baik dari sektor perekonomian, sektor pendidikan, sektor kepemerintahan, sektor transfortasi, sektor keagamaan, dan sektor sosial kemasyarakatan, dan masih banyak lagi. Berdasakan data dari BPS tahun 2020 (dalam www.bps.go.id. 2020) sektor perekonomian khususnya, mengalami penurunan hingga 5\% atau akan mendekati yang lebih rendah, konsumsi rumah tangga atau daya beli turun 5,07\% pada kuartal I 2019 ke 2,97\% pada kuartal II tahun 2020. Padahal ekonomi merupakan salah satu faktor penting dalam kehidupan manusia.

$\begin{array}{ll}\text { History: } & \text { Publisher: Undiksha Press } \\ \text { Received: 21 Mei } 2021 & \text { Licensed: This work is licensed under } \\ \text { Revised: 26 Juni } 2021 & \text { a Creative Commons Attribution 3.0 License } \\ \text { Accepted: 28 Juni } 2021 & \end{array}$


Penunjang terbesar perekonomian Indonesia didominasi dengan keberadaan Usaha Mikro, Kecil dan Menengah (UMKM) sebagai tulang punggung perekonomian nasional yang juga terkena dampak yang begitu serius. Dalam sensus ekonomi BPS tahun 2016 (dalam www.bps.go.id. 2016) Pendapatan Domestik Bruto (PDB) mencapai 60,34\%, ekspor sebesar $14,17 \%$, dan penyerapan tenaga kerja sebanyak $99,7 \%$. Besarnya peran UMKM terhadap kemajuan perekonomian di Indonesia menyebabkan pemberdayaan UMKM menjadi prioritas dalam ekonomi global. UMKM terdiri dari usaha mikro, usaha kkecil, ddan uusaha menengah. Dari pengklasifikasian UMKM tersebut, usaha mikro adalah usaha yang paling banyak ada di Kabupaten Buleleng tiap tahunnya. Hal ini dilihat dari data berikut.

Tabel 1. Perkembangan Jumlah UMKM di Kabupaten Buleleng (2018-2020)

\begin{tabular}{clccc}
\hline No & \multicolumn{1}{c}{ Klasifikasi Usaha } & Tahun 2018 & Tahun 2019 & Tahun 2020 \\
\hline 1 & Usaha Mikro & 25.202 & 26.048 & 26.362 \\
2 & Usaha Kecil & 9.140 & 9.294 & 9.381 \\
3 & Usaha Menengah & 193 & 196 & 196 \\
4 & Usaha Besar & 17 & 17 & 17 \\
& $\quad$ Total & 34.552 & 35.555 & 35.956 \\
\hline
\end{tabular}

Sumber : Dinas Perdagangan, Perindustriann dann Koperasi,uUsahak Kecilddan Menengah Kabupaten Buleleng, 2021

Menurut Dewi dan Martadinata (2018) usaha mikro adalah suatu usaha produktif yang dimiliki oleh perorangan dan/ badan usaha mikro yang memenuhi ciri-ciri sebagai usaha mikro. Ciri-ciri usaha mikro adalah mempunyai kekayaan bersih tidak melebihi $\mathrm{Rp}$ 50.000.000 tidak termasuk tanah dan bangunan tempat usaha, dan atau mempunyai hasil penjualan tahunan tidak melebihi Rp 300.000.000.

Selama pandemi kinerja usaha mikro mengalami penurunan. Berdasarkan data survei yang dilakukan oleh Lembaga Ilmu Pengetahuan Indonesia (2020) menunjukkan bahwa selama pandemi 94,69 usaha mengalami penurunan kinerja. Kinerja usaha mikro mengacu pada prestasi kerja/hasil kerja yang diraih oleh pelaku usaha mikro dari segi kualitas serta kuantitas dalam menyelesaikan berbagai tugas di dalam usaha dalam kurun waktu tertentu, kemudian akan dikaitkan dengan standar dan nilai yang ditentukan dari sebuah usaha (Arimbawa, 2016). Kinerja usaha mikro disebabkan 2 faktor yaitu faktor internal dan faktor eksternal Sentiago dan Hidayatulloh (2019).

Penurunan kinerja usaha mikro yang disebabkan oleh fenomena COVID 19 yang dapat dikaitkan dengan teori RBT (Resource Based Theory) bahwa apabila suatu perusahaan mempunyai kelebihan kompetitif, maka suatu perusahaan mampu mendatangkan nilai tambah guna meningkatkan kinerja perusahaan (Yasrawan, 2020). Kelebihan kompetitif dilihat dari sumber daya yang dimiliki usaha mikro. Selama pandemi COVID 19 sumber daya belum mampu dimaksimalkan oleh pelaku usaha mikro, sehingga hal ini menjadi masalah.

Banyak dampak yang diakibatkan oleh Pandemi COVID 19 yang juga melemahkan sektor usaha mikro sehingga pemerintah mengupayakan berbagai cara untuk memberikan dukungan dan bantuan termasuk kelonggaran membayar kredit, keringanan pajak, dan bantuan subsidi listrik maupun bantuan uang tunai. Menurut Apriyani, 2020 (dalam www.suara.com) dalam rangka membantu sektor UMKM tetap bertahan di situasi pandemi, pemerintah Indonesia memberikan BantuannLangsunggTunai b(BLT) UMKM atau disebut dengan BPUM. BPUM merupakan singkatan dari bantuan produktif usaha mikro. Pemerintah Indonesia sudah menargetkan 12 juta usaha mikro dengan anggaran sebesar 28,8 triliun untuk mendapatkan BPUM sehingga setiap pelaku usaha mikro akan menerima uang bantuan sebesar 2,4 juta rupiah. Di Kabupaten Buleleng, ribuan usaha mikro menerima BPUM yang telah terdata di Bank BRI Kanca Singaraja yang tersebar diseluruh kecamatan. Di Kecamatan 
Buleleng sendiri tercatat sebanyak 6.970 usaha mikro memperoleh BPUM. Melalui bantuan ini diharapkan usaha mikro tidak lagi mengalami kesulitan modal pada saat pandemi COVID 19. "Saya harapkan ini nanti, Banpres Produktif ini digunakan betul-betul untuk tambahan modal, untuk menambah barang-barang dagangan kita. Yang saya harapkan itu, "kata Presiden Jokowi (dalam Tambun, 2020). Namun faktanya dilapangan pengelolaan dana BPUM yang diperoleh oleh pelaku usaha mikro masih belum efektif dan belum tepat sasaran karena beberapa faktor. Menurut Apriyani, 2020 (dalam www.suara.com) pertama, sebagian besar pelaku usaha mikro menggunakan dana bantuan tersebut untuk kebutuhan sehari harinya tidak untuk kebutuhan usahanya serta pelaku usaha mikro belum menerapkan manajemen keuangan dengan baik. Kedua, tidak semua usaha mikro mampu mengakses informasi terkait bantuan ini. Ketiga, nilai bantuan yang diperoleh oleh pelaku usaha mikro belum mampu menutupi seluruh kerugian yang dialami selama pandemi. Keempat, angka keberhasilan penyaluran bantuan kurang jelas tolak ukurnya karena data statistik jumlah pelaku usaha mikro yang kurang akurat.

Tahun 2020 yang merupakan tahun yang berbeda dari tahun sebelumnya karena dihadapkan dengan masalah pandemiiCOVID119 pada zaman revolusii industri 4.0. Fenomena pandemiiCOVIDi19 dieeraarevolusiiindustrii 4.0 mengharuskan segala sektor usaha tak terkecuali UMKM memanfaatkan media teknologi dalam menjalankan usahanya. Pelaku UMKM dapat memanfaatkan kecanggihan teknologi saat ini untuk mengupgarde kualitasnya agar terus berjalan beriringan dengan kemajuan zaman. Isunya hanya sebagian UMKM yang sudah menggunakan teknologi akuntansi dan sebagian UMKM masih melakukan pembukuan secara manual bahkan tidak membuat pembukuan sama sekali padahal aplikasi pembukuan akuntansi sudah banyak disediakan di berbagai platform. Menurut Setianingrum (dalam https://mentari.news. 2019) menyatakan bahwa dari tahun 2015 hingga 2018 yaitu selama jangka waktu 3 tahun terdata sebanyak 1,7 Juta UMKM mengalami kebangkrutan yang diakibatkan oleh ketidakmampuan bersaing di era 4.0.

Permasalahan selanjutnya mengenai pentingnya human capital yang berkualitas. Human Capital merupakan bagian dari Intellectual capital yaitu aset tak berwujud. Aset tak berwujud ini merupakan asset yang paling mendasar yang biasanya dimiliki oleh setiap badan usaha termasuk usaha mikro. Hartati (2014) mengatakan bahwa humanccapital adalah aset yang cukup menarik karena setiap perusahaan memiliki human capital yang berdampak langsung pada kinerja UMKM. Human capital sangat jarang diperhatikan oleh pelaku usaha di Indonesia karena keberdaan yang tak terwujud.

Merujuk pada pemaparan diatas tujuan dilakukannya penelitian ini adalah untuk mengetahui pengaruh efektifitas penggunaan dana BPUM terhadap kinerja usaha mikro, untuk mengetahui pengaruh penggunaan software akuntansi terhadap kinerja usaha mikro, dan untuk mengetahui pengaruh human capital terhadap kinerja usaha mikro. Atas dasar itu penelitian ini mengambil judul "Pengaruh Efektifitas Penggunaan Dana BPUM, Penggunaan Software Akuntansi, dan Human Capital Terhadap Kinerja Usaha Mikro (Studi Pada Usaha Mikro Penerima Dana BPUM di Kecamatan Buleleng)"

Berdasarkan Peraturan Menteri Koperasi, Usaha Kecil dan Menengah Republik Indonesia Nomor 6 Tahun 2020 menyebutkan bahwa BPUM (Bantuan Produktif Usaha Mikro) merupakan bantuan dari pemerintah berupa uang tunai yang diberikan kepada pelaku usaha mikro yang dananya bersumber dari Anggaran Pendapatan dan Belanja Negara. Menurut Purwanto (2020) setiap pelaku usaha mikro akan memperoleh BPUM sebesar Rp 2.400.000/pelaku usaha.

Berdasarkan Resource."Based. Theory. (RBT), jika suatu perusahaan mengoptimalkan sumber, daya secara efektif maka perusahaan, tersebut dapat meningkatkan kinerjanya. Salah satu sumber daya perusahaan berupa aset berwujud yaitu dana BPUM. Menurut Yasrawan (2020) aset berwujud dalam suatu perusahaan dapat berupa aset tetap seperti peralatan dan 
aset lancar seperti perlengkapan, dan termasuk kas yang perlu mendapat pengelolaan secara efektif dan efesien. Kas sebagai modal kerja usaha mikro saat Pandemi COVID 19 ini beberapa berasal dari dana BPUM. Ketika pelaku usaha mikro dapat secara efektif menggunakan bantuan pemerintah untuk modal usaha maka manfaat dari BPUM akan menjadi maksimal. Hal ini dikarenakan BPUM yang diperoleh berfokus pada target penggunaan yang sudahdditentukanssebelumnya serta tidak digunakan untuk kepentingan lain, sehingga berdampak pada kinerja usaha mikro semakin meningkat.

Pada penelitian yang dilakukan oleh Yasrawan (2020) yang menyebutkan efektivitas penggunaan dana KUR berpengaruh positif serta signifikan terhadap kinerja UMKM pengguna dana KUR. Sementara itu penelitian dari Pramanik (2020) menyebutkan bahwa variabel bantuan langsung tunai memiliki pengaruh yang signifikan terhadap varibel kelangsungan hidup masyarakat di Padalarang. Dari penjelasan diatas dapat"dirumuskan"hipotesis"sebagai "berikut.

\section{$H_{1}$ : Efektivitas Penggunaan Dana BPUM Berpengaruh Positif dan Signifikan Terhadap Kinerja Usaha Mikro}

Menurut Ratnasari (2017) software akuntansi adalah program/perangkat lunak yang dirancang untuk memudahkan pencatatan keuangan akuntansi. Seluruh rangkaian kegiatan di bidang akuntansi dapat diselesaikan melalui prosedur akuntansi, seperti pembuatan jurnal, pembukuan buku besar, penyusunan neraca saldo, serta laporan keuangan. Dengan kehadiran software akuntansi pekerjaan pembukuan akuntansi menjadi lebih cepat.

Berdasarkan Resource.'Based. Theory. (RBT), jika suatu perusahaan mengoptimalkan sumber, daya secara efektif maka perusahaan, tersebut dapat meningkatkan kinerjanya. Salah satu" sumber"daya perusahaan berupa aset tidak berwujud yaitu software akuntansi. Berdasarkan Peraturan Menteri Keuangan Republik Indonesia Nomor 90/PMK.05/ 2019 menyatakan bahwa software akuntansi tergolong dalam aktiva tidak berwujud karena tidak mempunyai wujud fisik dan bukan merupakan bagian tak terpisahkan dari hardware komputer tertentu. Ketika pelaku usaha mikro mampu mengoptimalkan penggunaan software akuntansi maka laporan keuangan yang dihasilkan akan berkualitas sehingga kinerja usaha mikro juga akan ikut meningkat.

Pada penelitian Pasaribu (2019) menyebutkan bahwa perangkat lunak akuntansi berpengaruh positif dan signifikan terhadap kinerja perusahaan pada UMKM. Pada penelitian Sari (2012) menyebutkan bahwa pada penggunaan perangkat lunak akuntansi memberikan pengaruh posistif signifikan terhadap kinerja perusahaan pada UMKM. Pada penelitian Saifudin (2018) menyebutkan bahwa implementasi software akuntansi (Siskeudes) berpengaruh positif dan signifikan secara langsung terhadap kinerja perangkat desa Dari penjelasan diatas dapat" dirumuskan" hipotesis" sebagai berikut.

$\mathrm{H}_{2}$ : Penggunaan Software Akuntansi Berpengaruh Positif dan Signifikan Terhadap Kinerja Usaha Mikro

Menurut Muthaher dan Prasetyo (2014) mereka menyebutkan bahwasanya human capital dijadikan sebagai ekuitas atau modal yang berkaitan dengan sumber daya manusia di organisasi yang berupa motivasi, keahlian seseorang, sikap tanggung jawab, serta tingkat ketaatan karyawan.

Berdasarkan Resource "Based. Theory. (RBT), jika suatu perusahaan mengoptimalkan sumber, daya secara efektif maka perusahaan, tersebut dapat meningkatkan kinerjanya. Salah satu sumber daya perusahaan berupa aset tidak berwujud yaitu human capital. Menurut Hartati (2014) aktiva tidak berwujud salah satunya adalah intellectual capital, dimana salah satu bagian intellectual capital adalah human capital. Apabila perusahaan khususnya usaha mikro mempunyai SDM atau human capital yang unggul, maka perusahaan tersebut memiliki 
keunggulan kompetitif guna menunjang kinerja perusahaan. Human capital menjadi faktor pendorong meningkatkanya kinerja perusahaan.

Pada penelitian yang dilakukan oleh Yasrawan (2020) menyebutkan bahwa human capital berpengaruhh positifd dan signifikantterhadappkinerjaaUMKM.Artinya semakin baik human capital maka semakin baik pula kinerja UMKM. Sementara penelitian yang dilakukan Zuliyati, dkk (2017) menyebutkan bahwa terdapat pengaruh secara parsial antara human capital terhadap kinerja UMKM. Dari penjelasan diatas dapat dirumuskan" hipotesis"sebagai berikut.

$H_{3}$ : Human Capital Berpengaruh Positif dan Signifikan Terhadap Kinerja Usaha Mikro

\section{Metode}

Metode penelitian ini menggunakan metode kuantitatif dengan sumber data berupa data primer dan data sekunder. Tempat penelitian, berlokasi, di Kecamatan Buleleng.yakni pada usaha mikro yang menerima BPUM (Bantuan Produktif Usaha Mikro) yang telah didata di Bank BRI Kanca Singaraja.

Populasim merupakan daerah generalisasi yang mencangkup subjek dan objek yang mempunyai kualitas serta karakteristikktertentu yang ditentukan oleh peneliti dalam penelitian ini guna dipelajari kemudian ditarikk kesimpulannya (Sugiyono,2017). Pada penelitian, ini, yang,menjadi populasi ialah usaha,mikro, yang menerima BPUM (Bantuan Produktif Usaha Mikro) di Kecamatan Buleleng yang telah terdata di Bank BRI Kanca Singaraja pada bulan Januari 2021, dengan demikian, total populasi dalam penelitian ini berjumlah 6.970 usaha mikro. Sampel adalah bagian atau perwakilan dari populasi (Sugiyono,,2017). Pada penelitian, ini, penentuan, sampel menggunakan purposive,sampling. Purposive sampling adalah salah cara menentukan sampel, dengan menggunakan kriteriakriteria tertentu sebagai sampel. Dalam pengambilan sampel, peneliti menggunakan rumus slovin sehingga didapat sampel sebanyak 100 responden.

Metode pengumpulan dilakukan menggunakan kuesioner/angket dengan skalaa pengukuran yang dipergunakan pada penelitiannini ialah 5 skalaalikert. Penyebaran kuisioner dilakukan dengan menggunakan online dan offline.

Teknik analisis data menggunakan 3 uji yang meliputi uji kualitassdata (uji validitas dan uji reliabilitas), uji asumsi klasik (uji normalitas, uji multikolinieritas, dan uji heteroskedastisitas) danuuji hipotesis (analisis regresi linear, uji $t$ dan uji koefesien determinasi).

\section{Hasil dan Pembahasan}

Penyebaran kusioner dilakukan selama 1 bulan yaitu mulai awal bulan April 2021 hingga akhir bulan April 2021 kepada para pelaku usaha mikro penerima BPUM (Bantuan Produktif Usaha Mikro) di Kecamatan Buleleng. Berdasarkan waktu yang telah ditetapkan, peneliti berhasil mengumpulkan 100 kuesioner yang telah terisi lengkap.

Berdasarkan data-data hasil kuesioner yang telah dikumpulkan, kemudian dilanjutkan ke tahap analisis untuk mendapatkan karakteristik responden penelitian. Penelitian. ini menggunakan 7 karakteristik. responden sehingga didapat jenis usaha yang dijalani pelaku usaha mikro yang, menjadi responden, pada. penelitian. ini mayoritas usaha dagang yaitu sebanyak 69 usaha mikro dengan tingkat persentase 69\%, yang sudah berdiri 1-5 tahun sebanyak 35 usaha mikro dengan tingkat persentase $35 \%$. Pelaku usaha mikro yang menjadi responden penelitian ini mayoritas berjenis kelamin laki-laki yaitu sebanyak 52 orang dengan tingkat persentase 52\%, berusia 31-40 tahun yaitu sebanyak 32 orang dengan tingkat persentase 32\%, dengan pendidikan terakhir SMA/SMK sebanyak 63 orang dengan tingkat persentase $63 \%$. Pelaku usaha mikro yang menjadi responden pada penelitian ini mayoritas memperoleh BPUM pada bulan Agustus yaitu sebanyak 41 usaha mikro dengan tingkat 
persentase $41 \%$. Software akuntansi yang digunakan oleh pelaku usaha mikro yang menjadi responden pada penelitian ini mayoritas menggunakan software akuntansi berbasis mobile yaitu sebanyak 82 usaha mikro dengan tingkat persentase $82 \%$.

Kemudian dilakukan uji statistik deskriptif. Dalam statistik deskriptif ini, akan dipaparkan mengenai jumlah data, minimum, maksimum, mean, serta standar deviasi (Sugiyono, 2011).

Tabel 2. Hasil Analisis StatistikiDeskriptif

\begin{tabular}{llrrrr}
\hline & N & Min & Max & Mean & Std. Deviation \\
\hline Kinerja Usaha Mikro (Y) & 100 & 7 & 25 & 19.74 & 4.244 \\
Efektivitas Penggunaan Dana BPUM (X1) & 100 & 5 & 20 & 15.70 & 3.433 \\
Penggunaan Software Akuntansi (X2) & 100 & 6 & 20 & 15.35 & 3.666 \\
Human Capital (X3) & 100 & 6 & 30 & 22.71 & 5.990 \\
Valid N (listwise) & 100 & & & & \\
\hline Sul
\end{tabular}

Sumber : Hasil Output SPSS, 2021

Berdasarkan tabel diatas, dapat dideskripsikan bahwa terdapat 100 jumlah responden. Variabel Kinerja Usaha Mikro (Y) mempunyai nilai nilai minimum 7, nilai maksimum 25, nilai mean 19,74 dengan standar deviasi 4,244. Variabel efektivitas penggunaan dana BPUM (X1) memiliki nilai minimum 5, nilai maksimum 20, nilai mean 15,70 dengan standar deviasi 3,433 . Variabel penggunaan software akuntansi (X2) mempunyai nilai minimum 6, nilai maksimum 20, nilai mean 15,35 dengan standar deviasi yaitu 3,666. Variabel human capital (X3) mempunyai nilai minimum 6, nilai maksimum 30, nilai mean 22,71 dengan standar deviasi yaitu 5,990. Melihat nilai standar deviasi dan nilai mean. Ini berarti bawah standar deviasi lebih kecil dari nilai mean yang merepresentasikan bahwa penyimpangand data rendah. Penyimpangann dataa rendah artinya nilai data telah terdistribusi dengan merata.

Selanjutnya dilakukan pengukuran variabel penelitian dengan membandingkan nilai rata-rata pada hasil analisis statistik deskriptif tiap variabel dengan nilai kategorisasi pengukuran tiap variabel. Ada 5 kategori yang digunakan untuk mengukur variabel-variabel pada penelitian ini diantaranya sangat.rendah, rendah, cukup.tinggi, dan.sangat.tinggi. Sehingga didapat kinerja usaha mikro penerima dana BPUM di Kecamatan Buleleng berada pada kategori tinggi. Kategori tinggi menunjukkan usaha mikro penerima dana BPUM mempunyai kinerja usaha yang tinggi. Efektivitas penggunaan dana BPUM oleh usaha mikro di Kecamatan Buleleng berada pada kategori tinggi. Kategori tinggi menunjukkan usaha mikro penerima dana BPUM di Kecamatan Buleleng telah menggunakan dana BPUM dengan efektif untuk membiayai kegiatan operasional usaha mikro.Penggunaan software akuntansi oleh usaha mikro penerima dana BPUM di Kecamatan Bulelenggberadaapadaakategori tinggi. Kategori-tinggimmenunjukkan usaha mikro penerima dana BPUM di Kecamatan Bulelengmmemilikittingkat penggunaan software akuntansi yang tinggi. Human capital berada pada kategori tinggi. Kategori tinggi menunjukkan usaha mikro penerima dana BPUM di Kecamatan Buleleng memiliki tingkat human capital yang tinggi.

Uji kualitas data yang dilakukan ada 2 yaitu berupa uji validitas dan uji reliabilitas. Variabel kinerja usaha mikro (Y), efektivitas penggunaan dana BPUM (X1), penggunaan software akuntansi (X2), dan human capital (X3) mempunyai nilai Sig. (2-tailed) sebesar $0,000<0,05$ artinya seluruh butir pertanyaan pada kuesioner penelitian ini dapat dinyatakan valid. Berdasarkan hasil uji reliabilitas nilai Cronbach's alpha dari seluruh variabel yang digunakan pada penelitian ini lebih besar dari 0,60 artinya seluruh instrumen kuesioner yang digunakan untuk menjelaskan variabel Kinerja Usaha Mikro, Efektivitas Penggunaan Dana BPUM, Penggunaan software akuntansi, dan Human Capital dinyatakan reliabel atau andal sehingga dapat dipercaya sebagai alattukur variabel. 
Uji. asumsi. klasik. merupakan uji. yang. dilakukan untuk. mengetahui apakah. terdapat persoalan normalitas, multikolinieritas, dan heteroskedastisitas dalam model regresi linear berganda.

Tabel 3. Hasil UjinNormalitas

$\begin{array}{lll}\mathrm{N} & & \begin{array}{l}\text { Unstandardized } \\ \text { Normal Parameters }\end{array} \\ & & 100 \\ & \text { Mean } & .0000000 \\ \text { Most Extreme Differences } & \text { Std. Deviation } & 3.05339544 \\ & \text { Absolute } & .084 \\ & \text { Positive } & .055 \\ \text { Kolmogorov-Smirnov Z } & \text { Negative } & -.084 \\ \text { Asymp. Sig. (2-tailed) } & & .840 \\ \text { a. } & & .481\end{array}$

a. TesttdistributionnissNormal.

Sumber : Hasil Output SPSS, 2021

Dalam uji normalitas didapat nilai signifikansi One Sample Kolmogorov-Smirnov test yang ditunjukkan oleh Asymp. Sig. (2-tailed) bernilai 0,481 lebih besar dari 0,05 yang artinya data telah terdistribusi normal.

Tabel 4. Hasil Uji Multikolinieritas

\section{Variabel Bebas}

Efektivitas Penggunaan Dana BPUM (X1)

Penggunaan software akuntansi (X2)

Human Capital (X3)

\begin{tabular}{lc}
\multicolumn{2}{c}{ Collinearity Statistics } \\
\hline \multicolumn{2}{c}{ Tolerance } \\
.906 & 1.104 \\
.917 & 1.090 \\
.971 & 1.030 \\
\hline
\end{tabular}

Sumber : Hasil Output SPSS, 2021

Dalam uji multikolinieritas didapat nilai tolerance seluruh variabel independen pada penelitian ini lebih besar dari 0,10, yang artinya tidak ada korelasi antar variabel independen. Kemudian melihat nilai dari VIF (Variance Inflation Factor) seluruh variabel independen lebih kecil dari 10,00 berarti tidak ada korelasi antar variabel independen. Maka hasil pengujian mengindikasikan bahwa pada model-model regresi yang digunakan dalam penelitian ini tidak terjadi gejala multikolinieritas.

Tabel 5. Hasil Uji Heteroskedastisitas

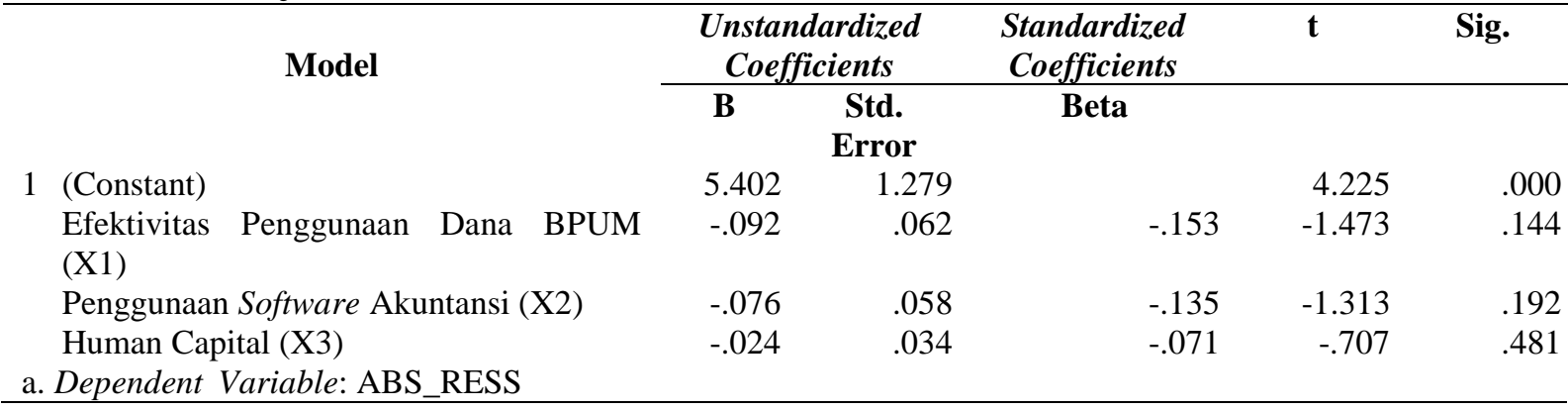

Sumber : Hasil Output SPSS, 2021

Dalam uji heteroskedastisitas didapat nilai signifikansi seluruh variabel independen pada penelitian ini lebih besar dari > 0,05, yang artinya dalam penelitian ini varian residualnya homogen atau dapat dikatakan model pada penelitian ini tidak mengalami gejala heteroskedastisitas. 
Kemudian dilakukan analisis regresi linear berganda digunakan untuk menguji hipotesis ada atau tidaknya pengaruh dua atau lebih variabel bebas terhadap variabel terikat (Ghozali, 2011) sebagai berikut.

Tabel 6. Hasil Analisis Regresi Linear Berganda

\begin{tabular}{|c|c|c|c|c|c|c|}
\hline \multirow{2}{*}{\multicolumn{2}{|c|}{ Model }} & \multicolumn{2}{|c|}{$\begin{array}{c}\text { Unstandardized } \\
\text { Coefficients }\end{array}$} & \multirow{2}{*}{$\begin{array}{c}\begin{array}{c}\text { Standardized } \\
\text { Coefficients }\end{array} \\
\text { Beta }\end{array}$} & \multirow[t]{2}{*}{$T$} & \multirow[t]{2}{*}{ Sig. } \\
\hline & & B & $\begin{array}{l}\text { Std. } \\
\text { Error }\end{array}$ & & & \\
\hline \multirow[t]{4}{*}{1} & (Constant) & 1.785 & 1.961 & & .911 & .365 \\
\hline & Efektivitas Penggunaan Dana BPUM (X1) & .598 & .095 & .484 & 6.276 & .000 \\
\hline & Penggunaan Software Akuntansi (X2) & .286 & .089 & .247 & 3.227 & .002 \\
\hline & Human Capital (X3) & .183 & .053 & .259 & 3.473 & .001 \\
\hline & Dependent Variable: Kinerja Usaha Mikro & & & & & \\
\hline
\end{tabular}

Berdasarkan pada tabel analisis diatas, persamaan model regresi linear berganda dapat dilihat sebagai berikut :

$$
\begin{aligned}
& \mathrm{Y}=\alpha+\beta 1 \mathrm{X} 1+\beta 2 \mathrm{X} 2+\beta 3 \mathrm{X} 3 \\
& \text { Kinerja Usaha Mikro }=1,785+0,598 \mathrm{X} 1+0,286 \mathrm{X} 2+0,183 \mathrm{X} 3
\end{aligned}
$$

Dari model regresi linear berganda, dapat diinterpretasikan bahwa konstanta sebesar 1,785 artinya bahwa apabila semua variabel independen nilainya 0 maka kinerja usaha mikro nilainya 1,785 .

Nilai koefisien regresi untuk variabel efektivitas penggunaan dana BPUM (X1) adalah sebesar 0,598 (positif). Artinya variabel efektivitas penggunaan dana BPUM memberi pengaruh kearah positif terhadap kinerja usaha mikro.

Nilai koefisien regresi untuk variabel penggunaan software akuntansi (X2) adalah sebesar 0,286 (positif). Artinya variabel penggunaan software akuntansi memberi pengaruh kearah positif terhadap kinerja usaha mikro.

Nilai.koefisien.regresi.untuk.variabel.human capital (X3) adalah sebesar 0,183 (positif). Artinya variabel human capital berpengaruh kearah positif terhadap kinerja usaha mikro.

Dilanjutkan dengan uji hipotesis berdasarkan tabel 6 ditunjukkan bahwa variabel efektivitas penggunaan dana BPUM secara parsial berpengaruh positif signifikan terhadap kinerja usaha mikro, yang dibuktikan denga nnilai Sig. $0,000<0,05$ dan nilai thitung 6,276> ttabel 1,664 serta nilai. koefisien. regresi. sebesar. 0,598 (positif). Maka berdasarkan hasil pengujian, $\mathrm{H}_{1}$ diterima yaitu variabel efektivitas penggunaan dana BPUM berpengaruh positif dan signifikan terhadap kinerja usaha mikro.

Variabel penggunaan software akuntansi secara parsial berpengaruh positif signifikan kinerja usaha mikro, yang dibuktikan dengannnilai Sig. 0,002 <0,05 dan nilai thitung 3,227 $>$ ttabel 1,664 serta nilai koefisien regresi sebesar 0,286 (positif). Maka berdasarkan hasil pengujian, $\mathrm{H} 2$ diterima yaitu variabel penggunaan software akuntansi berpengaruh positif dan signifikan terhadap kinerja usaha mikro.

Variabel human capital secara parsial berpengaruh positif signifikan terhadap kinerja usaha mikro, yang dibuktikan dengan nilai Sig. 0,001 <0,05 dan nilai thitung 3,473> ttabel 1,664 serta nilai koefisien regresi sebesar 0,183 (positif). Maka berdasarkan hasil pengujian, H3 diterima yaitu variabel human capital secara parsialn berpengaruh positif signifikan terhadap kinerja usaha mikro.

\begin{tabular}{|c|c|c|c|c|c|}
\hline Model & $\mathbf{R}$ & R Square & Adjusted R Squar & & Std. Error of the Estimate \\
\hline 1 & $.695^{\mathrm{a}}$ & .482 & & .466 & 3.10074 \\
\hline a. Predictors: & (Constant), & Capital & (X3), Penggunaan & Software & Akuntansi (X2), Efektivitas \\
\hline
\end{tabular}

Tabel 7. Hasil Uji Koefisien Determinasi 
Penggunaan Dana BPUM (X1)

\section{Pengaruh Efektivitas Penggunaan Dana BPUM Terhadap Kinerja Usaha Mikro}

Hasil pengujian parsial menunjukkan nilai koefisien regresi variabel efektivitas penggunaan dana BPUM terhadap kinerja usaha mikro sebesar 0,598. Ini berarti jika terjadi peningkatan efektivitas penggunaan dana BPUM sebesar 1 satuan, maka kinerja usaha mikro juga akan meningkat sebesar 0,598. Koefisien regresi efektivitas penggunaan dana BPUM terhadap kinerja usaha mikro bernilai positif, yang artinya terdapat hubungan positif antara efektivitas penggunaan dana BPUM dengan kinerja usaha mikro. Hasil pengujian parsial juga memperlihatkan bahwa nilai Sig. $0,000<0,05$ dan nilai thitung $6,276>t_{\text {tabel }} 1,664$ yang berarti $\mathrm{H} 1$ diterima. Hal ini menunjukkan bahwa efektivitas penggunaan dana BPUM berpengaruh positif dan signifikan terhadap kinerja usaha mikro. Semakin tinggi tingkat efektivitas penggunaan dana BPUM maka semakin tinggi juga kinerja usaha mikro di Kecamatan Buleleng.

Berdasarkan Resource Based Theory (RBT), jika suatu perusahaan mengoptimalkan sumber daya secara efektif maka perusahaan tersebut dapat meningkatkan kinerjanya. Salah satu sumber daya perusahaan berupa aset berwujud yaitu dana BPUM yang merupakan sumber modal kerja pada saat Pandemi COVID 19 untuk usaha mikro yang diberikan oleh penerintah. Dana BPUM yang disalurkan pemerintah kepada usaha mikro cukup besar, sehingga usaha mikro seharusnya memanfaatkan dana BPUM ini seefektif mungkin untuk keperluan usaha.

Berdasarkan pengukuran kategorisasi efektivitas penggunaan dana BPUM didapat hasil bahwa efektivitas penggunaan dana BPUM berada pada kategori tinggi. Ini berarti bahwa usaha mikro di Kecamatan Buleleng sudah menggunakan dana BPUM secara tepat dan efektif untuk membiayai kegiatan produktif usaha mikro seperti pembelian bahan baku, pembelian barang dagangan, dan aset lainnya. Ketika pelaku usaha mikro dapat secara efektif menggunakan bantuan pemerintah untuk modal usaha maka manfaat dari BPUM akan menjadi maksimal. Hal ini dikarenakan BPUM yang diperoleh usaha mikro digunakan sesuai dengan tujuan diberikannya BPUM tersebut oleh pemerintah dan tidak digunakan untuk tujuan lain, sehingga menyebabkan kinerja usaha mikro meningkat.

Hasil penelitian ini selaras dengan penelitian dari Yasrawan (2020) yang menyebutkan efektivitas penggunaan dana KUR berpengaruh positif serta signifikan terhadap kinerja UMKM pengguna dana KUR. Penelitian dari Pramanik (2020) menyebutkan bahwa variabel bantuan langsung tunai memiliki pengaruh yang signifikan terhadap variabel kelangsungan hidup masyarakat di Padalarang.

\section{Pengaruh Penggunaan Software Akuntansi Terhadap Kinerja Usaha Mikro}

Hasil pengujian parsial menunjukkan nilai koefisien regresi variabel penggunaan software akuntansi terhadap kinerja usaha mikro sebesar 0,286. Ini berarti jika terjadi peningkatan penggunaan software akuntansi sebesar 1 satuan, maka kinerja usaha mikro juga akan meningkat sebesar 0,286. Koefisien regresi penggunaan software akuntansi terhadap kinerja usaha mikro bernilai positif, yang artinya terdapat hubungan positif antara penggunaan software akuntansi dengan kinerja usaha mikro. Hasil pengujian parsial juga memperlihatkan bahwa nilai Sig. 0,002<0,05 dan nilai thitung 3,227 > $t_{\text {tabel }} 1,664$ yang berarti $\mathrm{H} 2$ diterima. Hal ini menunjukkan bahwa penggunaan software akuntansi berpengaruh positif dan signifikan terhadap kinerja usaha mikro. Semakin tinggi penggunaan software akuntansi maka semakin tinggi pula kinerja usaha mikro di Kecamatan Buleleng. 
Berdasarkan Resource Based Theory (RBT), jika suatu perusahaan mengoptimalkan sumber daya secara efektif maka perusahaan tersebut dapat meningkatkan kinerjanya. Salah satu sumber daya perusahaan berupa aset tidak berwujud yaitu software akuntansi. Software akuntansi sudah banyak disediakan diberbagai platform dan dimasa pandemi COVID 19 ini seluruh kegiatan usaha diharapkan memanfaatkan digitalisasi, sehingga usaha mikro seharusnya mampu memanfaatkan software akuntansi dalam membuat pembukuan keuangan.

Berdasarkan pengukuran kategorisasi penggunaan software akuntansi didapat hasil bahwa penggunaan software akuntansi berada pada kategori tinggi. Ini berarti bahwa usaha mikro di Kecamatan Buleleng sudah menggunakan software akuntansi secara baik untuk membantu pembukuan keuangan. Ketika pelaku usaha mikro mampu mengoptimalkan penggunaan software akuntansi maka laporan keuangan yang dihasilkan akan berkualitas sehingga kinerja usaha mikro juga akan ikut meningkat. Penggunaan software akuntansi oleh pelaku usaha mikro dalam pencatatan keuangan dapat meminimalisir kesalahan pembukuan akibat human errors seperti kesalahan menghitung, kesalahan memasukkan data, kerusakaan data keuangan, dan lain-lain. Apabila menggunakan software akuntansi hal-hal demikian dapat diminimalisir sehingga data keuangan yang dihasilkan lebih akurat untuk pengambilan keputusan usaha mikro.

Penelitian ini selaras dengan penelitian dari Pasaribu (2019) menyebutkan bahwa perangkat lunak akuntansi berpengaruh positif dan signifikan terhadap kinerja perusahaan pada UMKM. Pada penelitian Sari (2012) menyebutkan bahwa pada penggunaan perangkat lunak akuntansi memberikan pengaruh posistif signifikan terhadap kinerja perusahaan pada UMKM. Pada penelitian Saifudin (2018) menyebutkan bahwa implementasi software akuntansi (Siskeudes) berpengaruh positif dan signifikan secara langsung terhadap kinerja perangkat desa.

\section{Pengaruh Human Capital Terhadap Kinerja Usaha Mikro}

Hasil pengujian parsial menunjukkan nilai koefisien regresi variabel human capital terhadap kinerja usaha mikro sebesar 0,183. Ini berarti jika terjadi peningkatan human capital sebesar 1 satuan, maka kinerja usaha mikro juga akan meningkat sebesar 0,183. Koefisien regresi human capital terhadap kinerja usaha mikro bernilai positif, yang artinya terdapat hubungan positif antara human capital dengan kinerja usaha mikro. Hasil pengujian parsial juga memperlihatkan bahwa nilai Sig. $0,001<0,05$ dan nilai thitung 3,473 $>t_{\text {tabel }} 1,664$ yang berarti $\mathrm{H}_{3}$ diterima. Hal ini menunjukkan bahwa human capital berpengaruh positif dan signifikan terhadap kinerja usaha mikro. Semakin tinggi human capital yang dimiliki usaha mikro maka semakin tinggi pula kinerja usaha mikro di Kecamatan Buleleng.

Berdasarkan Resource Based Theory (RBT), jika suatu perusahaan mengoptimalkan sumber daya secara efektif maka perusahaan tersebut dapat meningkatkan kinerjanya. Salah satu sumber daya perusahaan berupa aset tidak berwujud yaitu human capital. Human capital dijadikan sebagai ekuitas atau modal yang berkaitan dengan sumber daya manusia di organisasi yang berupa motivasi, keahlian seseorang, sikap tanggung jawab, serta tingkat ketaatan karyawan.

Berdasarkan pengukuran kategorisasi human capital didapat hasil bahwa human capital berada pada kategori tinggi. Ini berarti bahwa usaha mikro di Kecamatan Buleleng sudah memiliki human capital yang tinggi.Ketika usaha mikro mempunyai SDM atau human capital yang unggul, maka perusahaan tersebut memiliki keunggulan kompetitif guna menunjang kinerja perusahaan. Human capital menjadi faktor pendorong meningkatkanya kinerja perusahaan.

Penelitian ini selaras dengan penelitian dari Yasrawan (2020) menyebutkan bahwa human capital berpengaruh positif dan signifikan terhadap kinerja UMKM. Artinya semakin baik human capital maka semakin baik pula kinerja UMKM. Sementara penelitian yang dilakukan 
Zuliyati, dkk (2017) menyebutkan bahwa terdapat pengaruh secara parsial antara human capital terhadap kinerja UMKM.

\section{Simpulan dan Saran}

Berdasarkan data yang sudah dikumpulkan dan sudah melalui proses pengujian statistik SPSS sehingga dapat ditarik simpulan, diantaranya (1) Efektivitas penggunaan dana BPUM berpengaruhnpositif dan signifikan terhadapkkinerja usaha mikro. (2) Penggunaan software akuntansi berpengaruhnpositif dan signifikan terhadapkkinerja usaha mikro. (3) Human capital berpengaruh positifkdan signifikanpterhadap kinerja usaha mikro

Berdasarkan pemaparan-pemaparan sebelumnya, penulis dapat memberikan beberapa saran terkait hasil penelitian ini diantaranya (1) Bagi pelaku usaha mikro agar memanfaatkan dana BPUM yang diperoleh lebih efektif dan tepat sasaran, mengoptimalkan penggunaan software akuntansi, dan menggali potensi dari human capital dengan cara mengembangkan potensi diri, mengembangkan kemampuan bisnis, menjalin hubungan baik dengan pelanggan dan menetapkan strategi bersaing untuk meningkatkan kinerja usaha mikro. (2) Bagi Pemerintah Kecamatan Buleleng agar melakukaan pembinaan dan pemberdayaan terhadap usaha mikro sehingga kinerja usaha mikro di Kecamatan Buleleng dapat ditingkatkan dan memberikan kontribusi kepada perekonomian daerah karena berdasarkan hasil penelitian efektivitas penggunaan dana BPUM, penggunaan software akuntansi, human capital, serta kinerja usaha mikro masih berada pada kategori tinggi yang masih dapat ditingkatkan lagi menjadi sangat tinggi. (3) Bagi peneliti selanjutnya disarankan untuk melakukan penelitian dilokasi yang berbeda dengan memperluas sampel penelitian, melakukan pengembangan penelitian dengan menambah variabel independen yang memiliki pengaruh lebih dominan terhadap kinerja usaha mikro.

\section{Daftar Pustaka}

Apriyani, Tri. 2020. Menakar Efektifitas BLT UMKM di Masa Pandemi COVID 19. Diunduh dalam www.suara.com. Diakses pada 26 Desember 2020.

Arimbawa, Dwitya. 2016. Pengaruh Literasi Keuangan terhadap kinerja dan keberlangsungan UMKM di Jawa Tengah. Jurnal Siasat Bisnis. Volume 20, Nomor 1 (hlm. 1-13).

BPS. 2016. Analisis Hasil Sensus Ekonomi 2016 Lanjutan. Potensi Peningkatan Kerja Usaha Mikro Kecil. Jakarta : Badan Pusat Statistik. Diunduh dalam www.bps.go.id. Diakses pada 26 Oktober 2020.

BPS. 2020. Ekonomi Indonesia Triwulan I 2020 Tumbuh 2,97 Persen. Jakarta : Badan Pusat Statistik. Diunduh dalam www.bps.go.id. Diakses pada 26 Oktober 2020.

Dewi, Putu Eka Dianita Marvilianti dan I Putu Hendra Martadinata. 2018. Akuntansi Koperasi dan UMKM. Singaraja: Undiksha Press.

Ghozali, Imam. 2011. Aplikasi Analisis Multivariate dengan program IBM SPSS 19. Semarang: Badan Penerbit Universitas Diponegoro.

Ghozali, Iman. 2013. Aplikasi Analisis Multivariate Dengan Program SPSS. Semarang: Badan Penerbit Undip.

Hartati, Noorina. 2014. Intellectual Capital Dalam Meningkatkan Daya Saing : Sebuah Telaah Litelatur. Jurnal Etikonomi, Volume 13, Nomor 1 (hlm 51-68). 
Lembaga Ilmu Pengetahuan Indonesia .2020. Survei Kinerja UMKM di Masa Pandemi COVID 19. Diunduh dalam www.lipi.go.id. Diakses pada 23 Januari 2021.

Muthaher, Osmad dan Iwan Nur Prasetyo. 2014. Pengaruh Modal Intelektual Terhadap ROE dan EPS Sebagai Proksi Kinerja Keuangan (Studi Empiris Pada Perusahaan Manufaktur yang Terdaftar di Bursa Efek Indonesia Tahun 2011 - 2013). EKOBIS, Volume 15, Nomor 2, (hlm $71-85)$.

Pasaribu, Lamtiur Saputri. 2019. Pengaruh Perangkat Lunak Akuntansi dan E-Commerce Terhadap Kinerja Perusahaan Pada Usaha Mikro, Kecil, dan Menengah di Lubuk Pakam. Skripsi, Universitas Sumatera Utara.

Peraturan Menteri Keuangan Republik Indonesia Nomor 90/PMK.05/2019 Tentang Pernyataan Standar Akuntansi Pemerintahan Berbasis Akrual Nomor 14 Tentang Akuntansi Aset Tak Berwujud.

Peraturan Menteri Koperasi, Usaha Kecil dan Menengah Republik Indonesia Nomor 6 Tahun 2020 tentang Pedoman Umum Penyaluran Bantuan Pemerintah Bagi Pelaku Usaha Mikro Untuk Mendukung Pemulihan Ekonomi Nasional Dalam Rangka Menghadapi Ancaman Yang Membahayakan Perekonomian Nasional Serta Penyelamatan Ekonomi Nasional Pada Masa Pandemi Corona Virus Disease 2019 (COVID 19).

Pramanik, Nuniek Dewi. 2020. Dampak Bantuan Paket Sembako dan Bantuan Langsung Tunai Terhadap Kelangsungan Hidup Masyarakat Pdalarang Pada Masa Pandemi Covid 19. Jurnal Ekonomi, Sosial \& Humaniora, Volume 01, Nomor 12, (hlm 113120).

Purwanto, Niken Paramita. 2020. Bantuan Fiskal Untuk UMKM Pada Masa Pandemi Covid19.Kajian Singkat Terhadap Isu Akutual dan Strategis, Volume 7, Nomor 17.

Ratnasari, Nuraida Wahyu. 2017. Analisis Faktor-Faktor Yang Mempengaruhi Penerimaan dan Penggunaan Software Akuntansi Dengan Pendekatan Technology Acceptance Model (TAM) (Studi Kausus pada UMKM di Kota Malang). Skripsi, Universitas Brawijaya.

Saifudin. 2018. Pengaruh Implementasi Software Akuntansi Terhadap Kinerja Perangkat Desa Dengan Perceived Enjoyment Sebagai Variabel Intererving. Jurnal Ilmiah Pendidikan Ekonomi, Volume 3 Nomor 2.

Sari, A.M. 2012. Pengaruh Perangkat Lunak Akuntansi dan E-Commerce Terhadap Kinerja Perusahaan Pada Usaha Mikro, Kecil, dan Menengah. Jurnal Vokasi Indonesia.

Sentiago, Bimo dan Amir Hidayatulloh. 2019. Analisis faktor eksternal terhadap faktor Internal dan Dampaknya Terhadap Kinerja UKM Daerah Istimewa Yogyakarta. Jurnal Manajemen dan Keuangan, Volume 8, Nomor 2, (hlm 123-134).

Setianingrum, Rani. 2019. 1,7 Juta UMKM Bangkrut. Tak Kuat Bersang Di Era 4.0. Dalam : https://mentari.news/209/04/17-juta-umkm-bangkrut-tak-kuat-bersaing-di-era-4-0. Diakses pada 27 September 2020. 
Sugiyono. 2011. Metode Penelitian Kuantitatif, Kualitatif dan R\&D. Alfabeta, CV: Bandung.

Sugiyono. 2017. Metode Penelitian Kuantitatif, Kualitatif, dan R\&D. Alfabet, CV: Bandung.

Tambun, Lenny Tristia. 2020. Presiden Tegaskan Banpres Produktif Untuk Tambahan Modal Kerja Pelaku Usaha Mikro. Diunduh dalam www.beritasatu.com. Diakses pada 26 Oktober 2020.

Yasrawan, Komang Tri. 2020. Pengaruh Efektifitas Penggunaan Dana KUR dan Intellectual Capital Terhadap Kinerja Usaha Mikro Kecil dan Menengah (Studi Pada UMKM Pengguna Dana KUR Se-Kabupaten Buleleng. Skripsi, Universitas Pendidikan Ganesha.

Zuliyati, dkk. 2017. Pengaruh Intellectual Capital Terhadap Kinerja UMKM. (Studi Kasus pada UMKM di Kabupaten Kudus). Jurnal Akuntansi dan Keuangan FEB Universitas Budi Luhur, Volume 6, Nomor 2, (hlm 181-200). 